Ryszarda BULAS

(Lublin, KUL)

\title{
ŚW. KUTBERT - ASCETA, BISKUP I ŚWIĘTY KOŚCIOŁA ANGLOSASKIEGO
}

Św. Kutbert był ascetą oraz jednym z najwybitniejszych postaci anglosaskiego Kościoła w VII wieku. Wykształcony w Northumbrii, w tradycji irlandzkiego monastycyzmu, poświęcił się życiu eremickiemu, a w ostatnich latach swego życia został powołany na biskupa Lindisfarne (Northumbria, płn. Anglia). Bertram Colgrave, autor krytycznego wydania żywotów św. Kutberta nazywa go „najbardziej znaną osobą wśród świętych północnej Anglii” woty św. Kutberta zawierają w sobie dużą część historii kościoła północnej Anglii, są świadectwem charakteru wczesnego monastycyzmu anglosaskiego, przesiąkniętego w VII wieku celtyckimi zwyczajami, charakterem skrajnej ascezy i kolorytem kulturowym, którego najważniejszą cechą jest szczególny stosunek do natury. Żaden żywot nie ma tyle wspólnego z żywotami irlandzkich mnichów, jak właśnie żywot św. Kutberta.

Życie św. Kutberta rekonstruujemy na bazie dwóch żywotów: anonimowego mnicha klasztoru w Lindisfarne i żywota Bedy Czcigodnego ${ }^{2}$. Żywot anonimowy powstał w czasach panowania króla Alhfritha (685-705) zwanych złotym wiekiem Northumbrii. Autorem jest nieznany mnich z klasztoru w Lindisfarne, a napisany został około 699 roku. Przetrwało do naszych czasów siedem kopii tego żywota z okresu IX-XIV wieku i wszystkie powstały na kontynencie. Beda (673-735) napisał najpierw w swej młodości krótką wierszowaną wersję żywota, a ok. 720 obszerną pisaną prozą, posiadającą 46 rozdziałów, tyle samo co krótki tekst metryczny ${ }^{3}$. Żywot pisany prozą oparty jest na

${ }^{1}$ Spośród najbardziej popularnych świętych całej Anglii B. Colgrave wymienia: Edmunda z Bury, Etiltryta z Ely i Kutberta z Durham. Tego ostatniego uważa za największego z nich, por. B. Colgrave (ed.), Two Life of Saint Cuthbert. A Life by an Anonymous Monk of Lindisfarne and Bede's Prose Life (text, trans. and notes), Cambridge - London - New York - Melbourne - Sydney 1940.

2 Omawia je i opisuje Colgrave, Two Life of Saint Cuthbert, s. 17-39.

${ }^{3}$ Na temat utworu metrycznego zob. W. Berschin, Opus deliberatum ac perfectum: , Why did the Venerable Bede write a second Prose Life of St Cuthbert?, w: G. Bonner - D. Rollason C. Stancliffe (eds.), St. Cuthbert, his cult and his community to AD 1200, Woodbridge 1989, 95-102. 
anonimowym Żywocie i zachował się w 38 manuskryptach z X-XV wieku. Colgrave podaje też 28 źródeł pisanych pochodzących z katalogów klasztornych, które świadczą o istnieniu w nich nie zachowanego do dziś Żywota św. Kutberta ${ }^{4}$. Wszystkie żywoty, szczególnie żywot Bedy, miały za wzór popularne w tym czasie Żywot św. Antoniego Atanazego w thumaczeniu Ewagriusza, Żywot św. Marcina Sulpicjusza Sewera, Actus Silvestri i Dialogi Grzegorza Wielkiego ${ }^{5}$. Ilość kopii żywotów św. Kutberta świadczy o rosnącej popularności jego postaci na kontynencie od IX wieku ${ }^{6}$. Są przesłanki, by sądzić, że na pocz. IX wieku rozwinął się także na kontynencie jego kult, o czym świadczy inskrypcja znajdująca się w kościele w Fuldzie ${ }^{7}$.

Po raz pierwszy anonimowy żywot wydali w 1668 roku Bollandyści w Acta Sanctorum Martii, natomiast tekst Bedy opublikował Johannes Hervagrius w 1563 r. w Bazylei, w zbiorze jego prac (t. III, col. 209-254) ${ }^{8}$.

1. Dzieciństwo i młodość św. Kutberta ${ }^{9}$. Św. Kutbert urodził się ok. 635 r. w rodzinie niższej klasy o saksońskim pochodzeniu, prawdopodobnie niedaleko Melros lub w okolicach Dunbar, przy ujściu Firth of Forth w dzisiejszej Szkocji ${ }^{10}$. W momencie narodzin Kutberta królestwo Northumbrii, pokonane

${ }^{4}$ Por. Colgrave, Two Life of Saint Cuthbert, s. 39-42.

5 Por. tamże, s. 11-12. C. Stancliffe omawia i porównuje obydwa żywoty wskazując na takie elementy żywota Bedy, które stylizują Kutberta na ideał mnicha-pasterza, stworzony przez św. Grzegorza Wielkiego. Wskazuje na elementy lączące go z Dialogami Grzegorza w części dotyczącej żywota św. Benedykta oraz z Vita Martini Sulpicjusza Sewera; tekst Bedy nazywa ,antytezą żywota anonimowego", zob. C. Stancliffe, Cuthbert and the polarity between Pastor and Solitary, w: Bonner - Rollason - Stancliffe (eds.), St. Cuthbert, his cult, s. 36-42. Zestawienie podobieństw żywotów anonimowego i Bedy z żywotami: Vita Antonii, Vita Martini, Vita Columbani i Dialogami Grzegorza Wielkiego, por. tamże, s. 43-44.

${ }_{6}$ Wspominają jego imię Martyrologia: Florusa z Lyonu, Wandalberta, Rabana Maura, Ado z Wiednia, Usuarda a także Martyrologia St. Gall Notkera i Codex Epternecensis w Martyrologium Hieronymianum, por. Colgrave, Two Life of Saint Cuthbert, s. 2.

${ }^{7}$ W 819 r., w kościele Chrystusa Zbawiciela w Fuldzie konsekrowano kryptę „,in absida occidentali, ubi martyr Bonifacius quiescit". Wśród świętych tam czczonych był także św. Kutbert i Beda Czcigodny, por. Colgrave, Two Life of Saint Cuthbert, 2.

${ }^{8}$ Por. Acta Sanctorum Martii, III, Antverpia 1668, 117-124. Bollandyści wydali tekst anonimowy w oparciu o manuskrypty z St. Omer i z Trewiru, zob. Colgrave, Two Life of Saint Cuthbert, s. 51.

9 Skrótowy rys biograficzny św. Kutberta oraz tło historyczne do jego życia umieszczają: B. Colgrave, St. Cuthbert and his time, w: C.F. Battiscombe (ed.), The Relics of Saint Cuthbert. Studies by various authors collected and edited with an historical introduction, Oxford 1956, 116-143; Colgrave, Two Life of Saint Cuthbert, s. 5-10; C. Stancliffe, Cuthbert, Pastor and Solitary, w: Bonner - Rollason - Stancliffe (eds.), St Cuthbert, his cult, s. 29-36 (An autline of Cuthbert's Life).

${ }^{10} \mathrm{O}$ kulcie św. Kutberta w Irlandii i o legendach, że był księciem irlandzkim, zob. P. Grosjean, The alleged Irish origin of St. Cuthbert, w: Battiscombe (ed.), The Relics of Saint Cuthbert., s. 144154; G. Phillips, St. Cuthbert's Native County, AnBol 13 (1894) 59-60; I. Pettit McKeehan, The Book of the Nativity St. Cuthbert, ,Publications of the Modern Language «Association of America»" 48 (1933) 981-999. 
przez króla Brytów Cadwallona i króla Mercian Pendy, przechodziło trudne chwile. Okupowanymi prowincjami Northumbrii, jak pisze Beda, król Brytów zarządzał jak tyran ${ }^{11}$. Jednak rok później, brat uwięzionego króla - Oswald, pokonał armię Brytów i wtedy dla Northumbrii nastały dobre czasy. Pobożny Oswald został jej królem, a mieszkańcy jego królestwa przyjęli chrześcijaństwo. W tym celu Oswald wysłał posłańców na wyspę Ionę do klasztoru św. Kolumbana po mnichów irlandzkich. W 635 r. przybył św. Aidan z mnichami i założył kilka klasztorów ${ }^{12}$. Jeden, zgodnie z tradycją irlandzką, na wyspie, w Lindisfarne, niedaleko królewskiego miasta Oswalda w Bamburgh. Lindisfarne nazwane zostało potem świętą wyspą, a klasztor stał się jednym z największych ośrodków monastycznych i kulturowych Anglii w VII i VIII wieku. Drugi klasztor założył w Melros na brzegu rzeki Tweed, trzeci w Hartlepool. We wszystkich zaprowadził regułę św. Kolumbana. Żył i nauczał zgodnie z tradycją irlandzką, podróżując, wędrując boso i nauczając Ewangelii ${ }^{13}$. Wiemy, że wyzwolił młodych anglosaskich niewolników i uczył ich przygotowując do pracy w kościele ${ }^{14}$. Być może św. Kutbert słuchał w tym czasie kazań św. Aidana.

W 642 r. Penda ponownie napadł na Northumbrię i pokonał Oswalda. Jego śmierć spowodowała podział Northumbrii na dwa królestwa: Deirę i Bernicię, do której należało Lindisfarne, rządzone odtąd przez młodszego brata Oswalda - Oswiu. W tym czasie Kuthbert był małym dzieckiem, który w wieku 8 lat został, jak podobni mu chłopcy, oddany pod opiekę foster-parents (opiekuńczych rodziców) w mieście Hruringaham, by otrzymać u nich wychowanie i poznać tajniki sztuki wojennej. Nic nie wiemy o jego opiekuńczym ojcu, ale jego opiekuńcza matka miała na imię Kenswith lub Coenswith ${ }^{15}$. Wtedy to miał Kutbert kontakt ze św. Aidanem, a ukształtowany przez mieszkańców klasztoru, starał się odciążyć ich w obowiązkach monastycznego życia.

Życie św. Kutberta zmieniło się ok. 17. roku życia ${ }^{16}$. Strzegł wówczas owiec na wzgórzach (jest możliwe, że nie był chłopcem do pilnowania owiec, ale wartownikiem - wychowany był bowiem na wojownika). Na nocnym niebie 31 VIII 651 r. zobaczył światło schodzące na ziemię i powracające do nieba wraz duszą św. Aidana, który rzeczywiście zmarł w nocy w Lindisfarne. Jest możliwe, że Kutbert już wcześniej rozważał wstąpienie do klasztoru, ale to wydarzenie było dla niego momentem decydującym. Poszedł więc do ufundo-

${ }^{11}$ Por. Historia ecclesiastica gentis Anglorum (= HE) III 1, SCh 490, 14-19.

12 Por. tamże III 3, SCh 490, 25-29.

13 Por. J.T. McNeill, The Celtic Churches. A History A.D. 200-1200, London 1874, 106.

${ }^{14}$ Por. P. Riché, Edukacja i kultura w Europie Zachodniej (VI-VIII w.), thum. M. RadożyckaPaoletti, Warszawa 1995, 330.

15 Por. Vita sancti Cuthberti auctore anonymo 2, 7, PL 94, 577; Vita sancti Cuthberti prosaica auctore Beda 14.

${ }^{16}$ Por. Vita sancti Cuthberti anonyma 4, 10. 
wanego przez Aidana klasztoru w Melrose, prowadzonego przez św. Boisila, prosząc o przyjęcie ${ }^{17}$, gdzie pozostał 13 lat. Opatem był wówczas Irlandczyk św. Eata, uczeń Aidana.

2. Wstąpienie do klasztoru. W 651 r., kiedy Kutbert wstąpił do klasztoru w Melrose, zmarł jego duchowy wzór - św. Aidan ${ }^{18}$. Nieznane są pierwsze lata jego pobytu w klasztorze, lecz choć był wówczas mnichem, istnieją przesłanki, by sądzić, że gdy w 655 roku Penda ponownie zaatakował osłabioną północ i zniszczył Bamburgh ${ }^{19}$, Kutbert był zaangażowany w działania militarne, o czym wspomina pewien anonimowy żywot ${ }^{20}$.

W latach 655-658 nastały dobre czasy dla Northumbrii. Wraz z Oswiu rządził jego syn Alhfrith, który ofiarował ziemie irlandzkiemu opatowi Melrose - św. Eatowi, w celu ufundowania nowego klasztoru w Ripon. Ponieważ wieść o pobożności, pilności i posłuszeństwie Kutberta rozniosła się i został włączony do grupy fundatorów Ripon, gdzie pełnił rolę ,praepositus hospitum", a w 661 r. został mianowany przeorem ${ }^{21}$. Jednak szybko zrezygnował z tej funkcji i opuścił Ripon, Alhfrith bowiem, zachęcony przez przybyłego z Rzymu Wilfrida, naciskał na przyjęcie rzymskich zwyczajów w kwestii święcenia Wielkanocy i rzymskiej formy chrześcijaństwa, której Kutbert, wychowany przez celtyckich mnichów z Irlandii, był wówczas przeciwny. Król Alhfrith odebrał też klasztor św. Eatowi i oddał Wilfridowi, a ci mnisi, którzy praktykowali celtycką tradycję, musieli wrócić do Melrose.

Kiedy Kuthbert wrócił w $661 \mathrm{r}$. do Melrose miał 20 lat ${ }^{22}$. Trzy lata później, w 664 r., klasztor zaatakowała szalejąca wówczas zaraza: umarł przeor Melrose, a Kutbert został jego następcą. W tym roku odbył się też słynny synod w Whitby, mający rozstrzygnąć, po której stronie ma opowiedzieć się Kościół: celtyckiej czy rzymskiej, w kwestii daty świętowania Wielkanocy ${ }^{23}$. Po synodzie Wilfrid został biskupem Northumbrii, a św. Eata opatem Lindisfarne. W rok po synodzie cała Northumbria, dotąd zdominowana przez celtycki monastycyzm zdecydowała zaprzestać kierownictwa duchowego Irlandii i część mnichów irlandzkich odesłałano do klasztoru na Iona ${ }^{24}$. Wydaje się, że po synodzie w Whitby w 664 r. także św. Eata i św. Kutbert zaakceptowali rzymskie zwyczaje i dlatego ten pierwszy zastał opatem, a drugi przeorem Lindisfarne.

7 Por. Vita sancti Cuthberti prosaica 6.

18 Por. tamże.

19 Por. Beda, HE III 16.

20 Por. Vita sancti Cuthberti anonyma 1, 7.

${ }^{21}$ Por. Vita sancti Cuthberti prosaica 7.

22 Por. tamze 8.

${ }^{23}$ Na temat synodu w Whitby zob. J. Strzelczyk, Iroszkoci w kulturze średniowiecznej Europy, Warszawa 1987, 34-35 i 77-81.

24 Por. Beda, HE III 28. 
Kiedy Kutbert przeniósł się do Lindisfarne miał ok. 30 lat i spędził tam następne 10 lat. Praca jego nie była łatwa. Przekonanie oponentów do rzymskich zwyczajów było zadaniem trudnym, ale uczynił to dzięki swojej cierpliwej naturze. Swój czas spędzał wśród ludzi, idąc z pomocą w ich duchowych potrzebach, prowadząc misjonarskie podróże, nauczając i czyniąc cuda. Jego praca misyjna miała szeroki zasięg, odwiedzał klasztory i był aktywnym misjonarzem od Lindisfarne do Whithorn i Carlisle (zob. mapa). Pełnił posługę misyjną, ale też fundował kościoły, np. oratorium w Dull, $\mathrm{z}$ dużymi kamiennymi krzyżami i małą celą dla siebie, gdzie potem powstał klasztor, a następnie Uniwersytet St. Andrews. Miał też w tym czasie ufundować kościół św. Kutberta w Edynburgu.

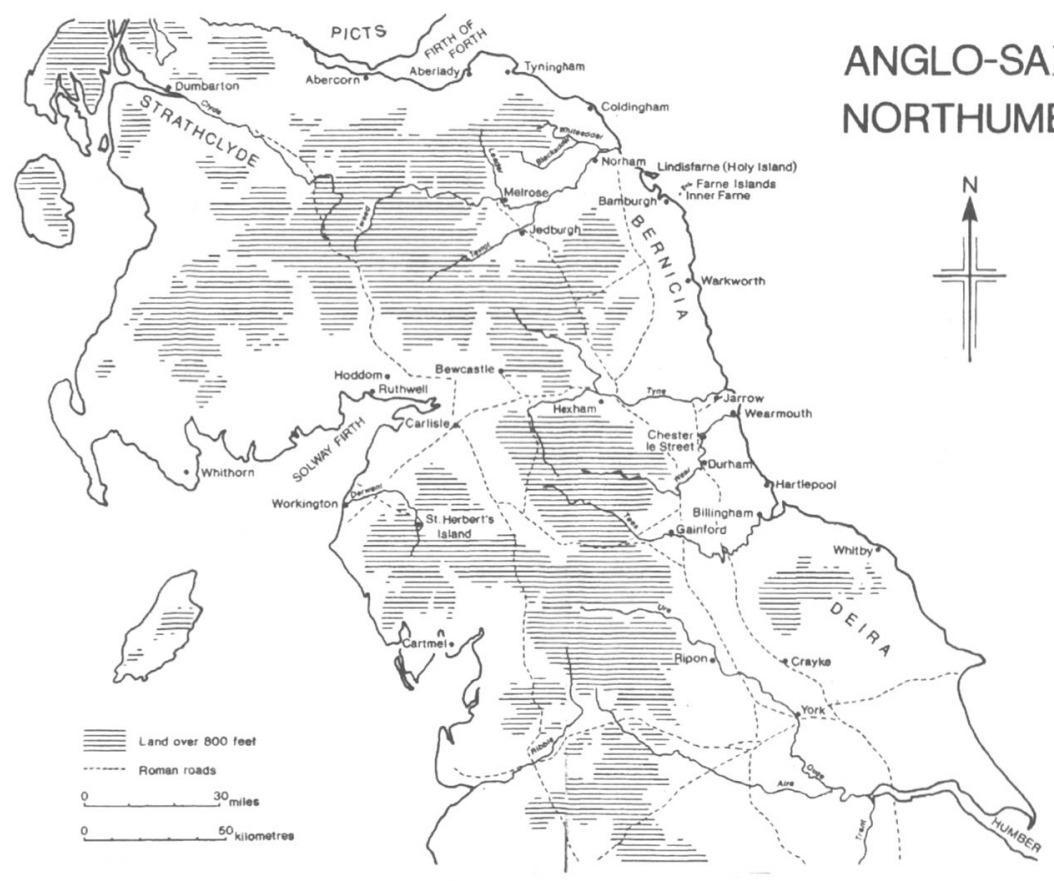

Mapa Northumbrii (Bernicia, Deira) w VII wieku, według: G. Bonner - D. Rollason - C. Stancliffe (eds.), St Cuthbert, his cult and his Community, Woodbridge 1989 (obwoluta).

Tymczasem sytuacja w kościele northumbryjskim bardzo się skomplikowała. W 666 r. po powrocie z Galii, Wilfrid zastał nową sytuację - pozbawiono go biskupstwa. Biskupem Northumbrii został św. Chad - Irlandczyk. Jednak po 3 latach arcybiskup Teodor z Canterbury przywrócił go na tron biskupi, a św. Chada posłał do Mercji w Lichfield. W tym czasie następują także duże zmiany 
w Kościele Northumbrii. W 678 r. arcybiskup Teodor realizując politykę dzielenia wielkich diecezji, podzielił diecezję Northumbrię na trzy nowe: Bernicję ze stolicą w Lindisfarne lub Hexham, Deirę z siedzibą w Yorku, i trzecią ze stolicą w Lindsay. Wilfrid był znany ze swej miłości do klasztoru w Lindisfarne, tego centrum celtyckiej „herezji” ${ }^{25}$, nie chciał więc łatwo zrezygnować ze swej pozycji w Northumbrii. Niezadowolony z sytuacji pojechał na skargę do Rzymu do papieża Agatona (678-681), by w 680 r. wrócić z zadawalającą go decyzją: wybrani biskupi zostali usunięci, a Wilfrid otrzymał prawo dobierania sobie asystentów.

W trakcie tych burzliwych dla Northumbrii wydarzeń i być może w reakcji na nie, w 676 r. św. Kutbert postanowił usunąć się do samotni na małej wysepce, 8 mil na południe od Lindisfarne, na Inner Farne, na której później żył przez 10 lat. Miał już wówczas 40 lat i uznał, że został przez Boga wezwany do życia w celi jako eremita. Realizował w ten sposób irlandzki ideał życia na morzu, rozumianym jako pustynia (,desert in the sea”). Była ona niezamieszkała, nie miała ani wody, ani drzew ani zboża. Kutbert wybudował sobie chatę i poprzez modlitwę uzyskał w cudowny sposób źródło. Zabrał ze sobą narzędzia gospodarskie, obsiał pszenicą, potem jęczmieniem. Chatę wybudował u wejścia do wyspy od strony Lindisfarne, by przyjmować braci, którzy przyjeżdżali tam na małych łodziach ${ }^{26}$. Przychodzili go zobaczyć, porozmawiać i prowadzić „niebieskie konferencje", a także prosząc go o uzdrowienie. Wiele dni w roku morze wokół wyspy uniemożliwiało dotarcie na nią; wówczas Kutbert był sam. Najpierw narzucał sobie praktyki ascetyczne myjąc podróżnym stopy, później jednak zamknął się swej celi i tylko otwierał okno, by błogosławić przybyłych i dawać duchowe rady bez opuszczania swej celi. Nie odmówił spotkania jedynie świętej opatce Alfledzie, którą ojciec - król Oswi, poświęcił Bogu w momencie jej urodzin, i która w 680 r. została opatką Whitby, następczynią św. Hildy ${ }^{27}$. Bardzo cenił sobie jednak samotność, która była dla niego nieprzerwaną modlitwą.

3. Konsekracja na biskupa. Na synodzie w Twiford prowadzonym przez arcybiskupa Teodora, który odbył się nad brzegiem rzeki Alne w królestwie Northumbrii w roku 685, uchwalono, że Kutbert powinien objąć biskupstwo w Lindisfarne ${ }^{28}$. Ani listy ani posłańcy nie byli w stanie zmusić go do tej posługi. Król Ecgfrith, który był obecny na synodzie i biskup Trumwinni oraz wielu innych popłynęli na wyspę i na kolanach nakłaniali go, by nie odrzucał misji, która mogła przynieść duszom tyle korzyści. Ich nacisk był tak silny, że święty

\footnotetext{
25 Por. Colgrave, Two Life of Saint Cuthbert, s. 9.

26 Por. Vita sancti Cuthberti prosaica 18.

27 Por. tamże, 23; Vita sancti Cuthberti anonyma 3, 6.

28 Por. Vita sancti Cuthberti anonyma 4, 1; Vita sancti Cuthberti prosaica 24-25.
} 
mimo gorzkich łez nie odmówił. Na biskupa został konsekrowany w Yorku, w święto Wielkanocy w roku 686, przez arcybiskupa Teodora w asyście 6 biskupów. Mimo konsekracji kontynuował jednak swoje praktyki ascetyczne, pamiętając o modlitwie, cały czas nauczając, karmiąc i chroniąc biednych ${ }^{29}$.

Przeczuwając zbliżającą się śmierć, św. Kutbert zrzekł się biskupstwa, które prowadził przez 2 lata i powrócił do swej samotni na wyspie Inner Farne wraz z dwoma mnichami wysłanymi przez Herefritha, opata Lindisfarne. Dwa miesiące później, gdy poczuł się chory, odwiedził go Herefrith i dał mu namaszczenie; wówczas Kutbert podniósł oczy, ścisną jego ręce i słodko zasnął w Chrystusie 20 III 687 roku. Zmarł na wyspie Farne, zgodnie jednak z jego życzeniem jego ciało zostało pochowane w klasztorze św. Piotra w Lindisfarne na prawo od dużego ołtarza; żył 53 lata.

4. Historia kultu ${ }^{30}$. Święty Kutbert słynął ze świętości, od czasu gdy został przeorem Lindisfarne, gdy żył jako asceta na Inner Farne, a także wtedy, gdy został biskupem. Jego ascetyzm był połączony z urokiem osobistym ${ }^{31}$. Pełny pogody ducha i wspaniałomyślności, często traktowany był jako duchowy przewodnik. Żył w stanie ciągłej modlitwy i często umartwiał się, dzięki czemu osiągnął taki stan, iż jak mawiano, przypominał bardziej anioła niż człowieka. Wielokrotnie spędzał całe noce na modlitwie unikając snu; czasami modląc się spacerował wokół wyspy. Pewnego razu jego bracia odkryli, że spędził kilka nocy na duchowych praktykach pozwalając sobie zaledwie na odrobinę snu lub wcale nie śpiąc. Kiedy św. Ebba, siostra króla św. Oswalda i Oswi, opatka podwójnego klasztoru w Coldingham, zaprosiła go do siebie by nabrał sił, pozostał tam kilka dni, jednak wykradał się, aby zgodnie ze zwyczajem, oddawać się ascetycznym praktykom. W nocy, gdy inni spali, jeden z mnichów, który szedł za nim, zastał go stojącego na nadbrzeżu, a następnie zobaczył, jak wszedł do wody po pachy i oddał się modlitwie - w ten sposób w ciszy spędził noc. Przed świtem wyszedł z wody modląc się przez chwilę na piasku, po czym powrócił do klasztoru, by przyłączyć się do porannego hymnu pochwalnego.

Tak bardzo płonął pragnieniem nieba, że nie mógł odprawić mszy bez łez, które też nierzadko towarzyszyły mu podczas słuchania spowiedzi. Potokiem łez bowiem poruszał często pokutnika wyznającego mu grzechy. Nade wszystko dążył do doskonałości, ale ten zapał do naprawy zawsze osłodzony był łagodnością i dobroczynnością. Walczył usilnie ze swoimi namiętnościami, był bowiem porywczy i żarliwy w walce o sprawiedliwość, ale nigdy nie pozwolił by to zakłóciło spokój i łagodność jego umysłu. Mimo że szukał samot-

${ }^{29}$ Por. Vita sancti Cuthberti prosaica 26.

${ }^{30} \mathrm{Na}$ temat historii kultu zob. C.F. Battiscombe, Introduction, w: Battiscombe (ed.), The Relics of Saint Cuthbert, s. 22-98; A. Thacker, Lindisfarne and the origins of the cult of St Cuthbert, w: Bonner - Rollason - Stancliffe (eds.), St. Cuthbert, his cult and his community, s. 103-122.

${ }^{31}$ Por. Vita sancti Cuthberti prosaica 16. 
ności, a kontakt z Bogiem był dla niego nader ważny, miał też na uwadze wszystkie współczesne mu wydarzenia, do których miał podejście zawsze tak samo pogodne. Siła jego miłości i przepełniona radością dusza wynikały z jego zdolności dostrzegania Boga w każdym wydarzeniu. Miał też dar prorokowania. Pewnego razu, w 685 r., kiedy odwiedził królową w Carlisle, miał objawienie, że jej mąż jest więziony przez Piktów i że poniósł w bitwie śmierć ${ }^{32}$. Miał także dar uzdrawiania, a leczył wodą, którą wcześniej pobłogosławił. W ten sposób wyleczył żonę szlachcica, która leżała niema, nieprzytomna i bliska śmierci. Umiejętność ta i intuicja sprawiły, że wielu się z nim konsultowało nadając mu imię „Taumaturga Brytanii” lub nazywając „Ogniem Północy”33.

Kiedy św. Kutbert zmarł, tzn. 20 marca 687 r., został pochowany w kościele w Lindisfarne na prawo od ołtarza. Ponieważ od dawna słynął z czynionych cudów, od końca VII wieku jego kult zaczął szybko się rozszerzać. Jedenaście lat później, po długich konsultacjach, zdecydowano ekshumować jego szczątki. Grób otwarto 20-go marca 698 r. i znaleziono w nim „,nietknięte ciało”; fakt ten potwierdził jego świętość i pomógł w popularyzacji jego kultu. Beda Czcigodny pisze, że wielu wówczas zostało uzdrowionych dzięki styczności z jego relikwia$\mathrm{mi}^{34}$. Ciało zostało umiejscowione w bardziej odpowiedniej dla kultu, drewnianej skrzyni-relikwiarzu ${ }^{35}$. Następnie wniesiono je do wnętrza kościoła, ponad poziom posadzki. Te wydarzenia korespondowały z jego kanonizacją . Drewniana trumna-relikwiarz stała się centrum jego kultu i repositorium licznych darów ku jego czci, które z czasem stały się relikwiami przez kontakt z jego szczątkami.

W VIII i IX wieku o losach relikwii zadecydowały najazdy z północy. Mimo najazdu Wikingów w 793 r., mnisi pozostali w klasztorze, następny jednak wielki najazd zmusił ich do opuszczenia Lindisfarne w 875 roku. W swoją wieloletnią wędrówkę wzięli relikwie św. Kutberta wraz z głową św. Oswalda, króla Northumbrii, kilka kości św. Aidana, założyciela Lindisfarne oraz szczątki trzech sukcesorów Kutberta - bpa Eadberhta, Eadfritha i Aethilwalda. Mnisi związani z relikwiami św. Kutberta podróżowali po Cumbrii, gdzie na pamiątkę tych podróży dedykowano mu kościoły, mnisi zaś stali się znani jako „Kongregacja św. Kutberta”. O tej Kongregacji wspomina przekaz w Cumbrii, gdzie jest także mowa, że chcieli pojechać do Irlandii, ale wielki sztorm ich zawrócił, zagubiono bowiem Ewangelię, która po czasie została odnaleziona niezniszczona ,kilka mil od brzegu”36. Historia łączy ową

${ }^{32}$ Por. tamże 27.

33 Por. tamże 29-31; D. Adam, Fire of the North: the life of St. Cuthbert, London 2003.

34 Por. Vita sancti Cuthberti prosaica 44-46.

35 Relikwiarz opisuje i analizuje styl jego dekoracji E. Kitzinger, The Coffin - Reliquary, w: Battiscombe (ed.), The Relics of Saint Cuthbert, s. 202-304.

${ }^{36}$ Por. D.H. Wright, Book reviews (C.F. Battiscombe (ed.), The Relics of Saint Cuthbert, Oxford 1956), ,,The Art Bulletin” 43 (1961) 142. 
księgę ze słynnym ewangeliarzem z Lindisfarne, który prawdopodobnie nieśli mnisi z sobą wraz z relikwiarzem „na chwałę Boga i św. Kutberta”. Kilka lat później jest poświadczona obecność Kongregacji w Craike w Yorkshire. W 883 r. mnisi osiedlili się w rzymskim Chester-le-Street, gdzie spędzili ponad 100 lat aż do 995 roku $^{37}$.

Okresem prosperity dla relikwiarza i Kongregacji był X wiek. Wielu było bowiem znamienitych gości i beneficjantów np. król Athelstan, który odwiedził relikwie w 934 roku $^{38}$. Jednym z jego wielu darów była księga Ewangelii, znajdująca się dziś w British Museum, w kolekcji Cottona (Otho B. IX), ale o niej jako darze króla wiemy z inskrypcji w j. angielskim zawierającej listę królewskich darów dla relikwii. Lista ta przetrwała w łacińskiej wersji w Historia de Sancto Cuthberto ${ }^{39}$. Innym jego darem była kopia dzieła Bedy: Vita Sancti Cuthberti, przechowywana dziś w Cambridge (Corpus Christi College, MS 183), które zawiera obraz przedstawiający Athelstana przekazującego księgę Świętemu. W końcu X wieku duńscy najeźdźcy znowu zagrozili Northumbrii, bp. Aldhun przeniósł więc Kongregację i relikwiarz w 995 r. do klasztoru w Ripon. Po kilku miesiącach mnisi chcieli przenieść się powtórnie do Chester-le-Street, ale ostatecznie osiedlili się kilka mil od Cheester-le-Street, na wzgórzu Durham, które było naturalnym miejscem obronnym, a także dobrym miejscem do życia z regularnie oranymi i obsiewanymi polami.

Relikwie pozostały w Durham przez następne tysiąc lat, aż do dnia dzisiejszego $^{40}$. Na początku XI wieku, mnich o imieniu Aelfred Westou, prowadzony licznymi wizjami opiekował się relikwiarzem w sposób szczególny. Kolekcjonował relikwie innych northumbryjskich świętych, w tym Bedy, którego relikwie złożył do relikwiarza. Król Kanut Wielki (1016-1035) jako pielgrzym odwiedził relikwiarz i odnowił tradycję królewskich beneficjów. Po najeździe Normanów, biskup Aethelwine w 1069 r. przeniósł Kongregację i relikwiarz dla większego bezpieczeństwa do Lindisfarne, ale wróciła ona do Durham w marcu 1070 roku. W 1083 r. biskup William z St. Calais sprowadził do Durham grupę benedyktynów i zdecydował się wybudować nową katedrę:

${ }^{37}$ Por. E. Cambridge, Why did the Community of St. Cuthberty settle at Chester-le-Street?, w: Bonner - Rollason - Stancliffe (eds.), St. Cuthbert, his cult and his community, s. 367-386.

${ }^{38}$ Por. L. Simpson, The King Alfred/St. Cuthbert Episode in the Historia de Sancto Cuthberto: its significance for mid-tenth-century English History, w: Bonner - Rollason - Stancliffe (eds.), St. Cuthbert, his cult and his community, s. 397-411, spec. 405-406.

${ }^{39} \mathrm{Na}$ temat Historia de sancto Cuthberto por. D. Rollason, St Cuthbert and Wessex: the evidence of Cambridge (Corpus Christi College MS 183), w: Bonner - Rollason - Stancliffe (eds.), St. Cuthbert, his cult and his community, s. 413-424.

${ }^{40}$ Por. D. Hall, The Sanctuary of St. Cuthbert, w: Bonner - Rollason - Stancliffe (eds.), St Cuthbert, his cult and his community, s. 425-436; A.J. Piper, The first generations of Durham Monks and the cult of St Cuthbert, w: tamże, 437-446. 
zaczął w 1093 r., a skończył na pocz. XII wieku ${ }^{41}$. W 1104 r. nowy budynek był gotowy do przechowania relikwii św. Kutberta, a 29 sierpnia nastąpiła translacja relikwii ${ }^{42}$. Wówczas relikwiarz został jeszcze raz otwarty przez sceptyków, którzy mieli ponownie zobaczyć ciało Świętego nietknięte. Relikwiarz złożono na kamiennym piedestale w apsydzie nowej katedry. Stara skrzynia-relikwiarz została umieszczona wewnątrz nowej skrzyni, pokrytej skórą i związanej żelazem, ta zaś była zamknięta w trzeciej skrzyni dekorowanej złotem i cennymi kamieniami. Co się działo po translacji w 1104 r., nie wiemy. Popularność kultu jednak rosła i w końcu XII wieku św. Kutbert był jednym z najbardziej znanych świętych w Anglii. Wiadomo też, że w 1372 roku kamienny piedestał relikwiarza został odbudowany ${ }^{43}$.

W XVI wieku, w grudniu 1539 r., powstała Komisja Henryka VIII, która miała na celu zniszczenie religijnych monumentów oraz konfiskatę cennych metali i biżuterii, pozostawiła jednak ciało św. Kutberta nietknięte i inne jego relikwie jako te, które nie miały wartości komercjalnej. Zostały one pochowane pod podłogą katedry w 1542 roku. Sukcesorzy Kongregacji św. Kutberta w 1539 r. zostali poddani reorganizacji, a w 1542 r. rozwiązani.

W XIX wieku grób św. Kutberta został ponownie otwarty 17 maja 1827 $\mathrm{roku}^{44}$. Znaleziono wówczas ciało w pełnym ubiorze, i inne relikwie, nie skonfiskowane w 1542 roku. Relacja z tego wydarzenia została opublikowane przez Jamesa Raine'a, katedralnego bibliotekarza ${ }^{45}$. Odkryty grób zawierał skrzynię wykonaną w 698 r., wspaniały złoty krzyż na pierś, grzebień z kości słoniowej, manuskrypt Ewangelii św. Jana, przechowywany dziś w Stonyhurst College, haftowane ubranie podarowane przez króla Athelstana, trzy bizantyjskie jedwabie i fragmenty innych tekstyliów. Niestety grób był otwarty tylko jeden dzień, a prace nad nimi były nieudolne i destrukcyjne $\mathrm{z}$ punktu widzenia współczesnych standardów. Opisy Raine’a są jednak dobre i szczegółowe ${ }^{46}$. Raport z 1899 r. informuje, że w 687 r. ciało św. Kutberta było balsamowane i stąd wynikała sława o nienaruszalności jego ciała w średniowieczu ${ }^{47}$.

${ }^{41}$ Por. V. Tudor, The cult of St Cuthbert in the Twelfth century: the evidence of Reginald of Durham, w: Bonner - Rollason - Stancliffe (eds.), St Cuthbert, his cult and his community, S..447-467.

${ }^{42}$ Przekazy pisane na temat tej translacji (anonimowy i Reginalda z Durham) cytuje C.F. Battiscombe, por. Introduction, w: Battiscombe (ed.), The Relics of Saint Cuthbert, s. 99-114. 43 Por. Wright, Book reviews, s. 143.

${ }^{44}$ O badaniach z roku 1827 zob. R.N. Bailey, St Cuthbert's Relics: some neglected evidence, w: Bonner - Rollason - Stancliffe (eds.), St Cuthbert, his cult and his community, s. 231-246; J.T. Fowler, On an Examination of the Grave of St Cuthbert, ,Archaeologia” 57 (1900) 11-28.

${ }^{45}$ Por. J. Raine, Saint Cuthbert: with an account of the state in which his remains were found upon the opening of his Tomb, Durham 1828.

46 Relacjonuje je C.F. Battiscombe, por. Introduction, w: Battiscombe (ed.), The Relics of Saint Cuthbert, s. 8-9.

${ }^{47}$ Por. Fowler, On an Examination of the Grave of St Cuthbert, s. 11-28. 
Kult św. Kutberta objął całą Anglię. Stwierdza się w Anglii 130 kościołów pod jego wezwaniem: 17 znajduje się w Szkocji, a reszta głównie w Północnej Anglii, w Cumbrii oraz w kilku innych częściach Angliii ${ }^{48}$. Także pewne nazwy miejscowości są pamiątką po nim, jak Kirkcudbright w Szkocji, Cotherstone w Yorkshire, Cubert w Kornwalii. W Cumbrii kościoły mu dedykowane leżą wzdłuż doliny Eden, w południowym Carlisle. Jest możliwe, że kilka kościołów było wybudowanych później, na miejscu tych powstałych u schyłku VIII wieku. W Aldingham w XII-wiecznym kościele znajduje się krzyż sugerujący, że mnisi podczas swej wędrówki mogli pozostawić w nim kości św. Kutberta. Inny kościół św. Kutberta znajduje się w Kirkby in Furness. Kult jego ciągle rósł i wiele kościołów dedykowano mu w XIII wieku. O tym kulcie świadczy też XV-wieczna seria obrazów o życiu św. Kutberta oparta na manuskrypcie z Durham, który miał być złożony w chórze katedry w Carlisle ok. 1475 roku $^{49}$. Przede wszystkim to katedra w Durham, miejsce stałego pobytu Kongregacji św. Kutberta jest centrum pamiątek po Świętym. Znajdują się tam nie tylko jego grób i relikwiarz, ale także freski poświęcone jego postaci ${ }^{50}$.

Św. Kutbert żyjąc na Inner Farne ustanowił specjalne prawa dla ochrony kaczek i innych ptaków wodnych, zakładających gniazda na wyspie. Są to być może pierwsze w świecie prawa ochronne dla ptaków. We współczesnym dialekcie northumbryjskim kaczki są nazywane „,cuddy ducks”(kaczki Kutberta). Dlatego wyspa, na której św. Kutbert wiódł życie eremickie, Inner Farne jest dziś rezerwatem przyrody, pod opieką National Trust; wraz z klasztorem w Lindisfarne są miejscem pielgrzymek w dzień św. Kutberta przypadającym 20 marca.

Na koniec trzeba wspomnieć, jak wiele łączy postać św. Kutberta i Bedę Czcigodnego. Beda żył w atmosferze świętości i kultu Kutberta oraz w miejscu objętym jego działalnością misyjną. Obaj zostali pochowani w katedrze w Durham, a w okresie wczesnośredniowiecznym istnieją na kontynencie ślady połączonego kultu obu - świętego i uczonego.

${ }^{48}$ Hampshire, Somerset, Cornwall, Leicestershire, Herefordshire, Bedfordshire, Norfolk, Dorsetshire, Somersetshire, por. A. Hamilton Thompson, Churches dedicated to St. Cuthbert, w: Transactions of the Architectural and Archaeological Society of Durham and Northumberland. Durham 1936, 151nn.

49 Por. B. Colgrave, The St. Cuthbert paintings on the Carlisle Cathedral stalls, „Burlington Magazine for Connoisseurs" 73 (1938) nr 424, 16-21.

50 Por. E.T. Ling. Wall paintings at Durham and Easby, „Burlington Magazine for Connoisseurs" 76 (1941) nr 464, 166-169. 


\section{ST. CUTHBERT, ASCET, BISHOP AND SAINT OF ANGLO-SAXON CHURCH}

(Summary)

The author presents one of the best-known figures of northumbrian Church, in time of the transitional period from paganism to Christianity. On the base of two Lives of St. Cuthbert (The Anonymous life, Bede's prose life) author describe life of Saint (childhood, youth, a monk, solitary life, a prior of Melrose and Lindisfarne, bishop of Northumbria). Finely author describes the spread of the cult of St. Cuthbert in Ireland, Scotland, North of England and Continent. 